\title{
Social and epidemiological determinants of gonorrhoea in an East African country
}

\author{
A. R. VERHAGEN* AND W. GEMERT $\dagger$ \\ From the ${ }^{\star}$ Department of Medicine, University of Nairobi, and the + Medical Research Centre, Nairobi, Kenya
}

Exact data concerning the social and epidemiological aspects of gonorrhoea and other venereal diseases are scarce. Even in countries where there are many opportunities for research this is a rather neglected aspect and the findings in those areas may not apply to the rather different society in developing tropical countries. We therefore endeavoured to study these aspects during an investigation of which the bacteriological data have been published in another paper (Verhagen, Van der Ham, Heimans, Kranendonk, and Maina, 1971).

\section{Methods and material}

\section{(1) THE CLINICS}

We refer to this previous paper (Verhagen and others, 1971) for a detailed description; the smallest clinic (Nyeri) has been disregarded in the present investigation, because of problems in collecting controls.

The procedure may be summarized as follows:

All patients suspect for gonorrhoea were investigated by a special team in seven government and city council clinics in various parts of Kenya. Six clinics were open to the general public; one (Timboni in Mombasa) was exclusively for prostitutes, who came for a monthly check-up, whereas in all other clinics patients reported spontaneously. Nairobi and Mombasa (in this last town a general clinic was also investigated) are large cities, Kisumu and Kericho are provincial towns, and Kitui and Machakos will be termed 'rural areas', because they are small rural administrative centres in which over 80 per cent. of the patients were farmers from the surrounding villages and hamlets. The clinics were grouped in these three categories.

\section{(2) THE PATIENTS}

The patients were divided into four groups according to sex and diagnosis.

The methods used to confirm the diagnosis in men and women with gonorrhoea (abbreviated M-GON and

Received for publication October 12,1971

Address: Medical Research Centre, P.O. Box 49370, Nairobi, Kenya The Research centre is a Department of the Royal Tropical Institute Amsterdam, The Netherlands
F-GON) have been described (Verhagen and others 1971).

Virtually all the male patients with negative culture and smear results for gonococci (M-NEG) had a nonspecific urethritis (NSU), often post-gonorrhoeal; for all practical purposes this disease can also be considered to be of venereal origin.

The female patients in whom no gonorrhoea was found (F-NEG) form a heterogeneous group. Some had infections analogous to NSU in the male patients, some had a discharge and a history of possible infection, and in some gonorrhoea may have been missed as usually only one investigation was done. The majority seemed to have many types of gynaecological and other complaints related to the lower abdomen. This group differed considerably from the other three, which consisted of V.D. patients.

\section{(3) THE CASE-HISTORIES}

All patients were questioned by two assistants according to a uniform questionnaire standardized during a training period; the assistants were interchanged regularly.

The questions included:

(a) Demographic data such as tribe;

(b) Social background;

(c) the history such as sexual contact directly pertaining to a possible gonococcal infection.

(4) CONTROLS

For every patient (both those with gonorrhoea and those who were suspect but had negative bacteriological findings) there was one control. The controls were adult patients visiting the same clinic with non-venereal complaints. An excess number of controls was first questioned and subsequently every patient was randomly matched for sex and age with a control at the same clinic. No controls could be questioned in the special prostitute clinic (Mombasa-Timboni) and data from this selected group will be mentioned only in the paragraph discussing prostitution (Results-5). Some questions included under (c) were too intrusive to be put to controls; the patients and controls could be compared only for demographic and social data.

(5) PROCESSING

Duplicated coding (see Results) of all answers with subsequent elimination of mistakes was performed. For 
every patient there were twenty variables (exclusive of the bacteriological and clinical results), for the controls fifteen. All data were processed at the Computer Centre of The University of Nairobi. This consisted of tabulation of all the data per clinic-group (large towns, small towns, and rural areas), sex, diagnosis, and cross-tabulation of the most important data in these same groups and a discriminant analysis.

This latter can be applied if one is dealing with two or more groups, the members of which are characterized by more than one quantitative variable. It analyses these simultaneously, thus taking into account the correlation between variables, aiming at maximizing the difference between means between the groups, using a weighted sum of the variables. A detailed description is inappropriate here, but a specific example may be given as follows: It may be found in extracting the combination of variables, that on the one hand one of two (or more) variables which produces significant differences between the groups is dependent on the other (e.g. 'level of job' on 'education'), whereas on the other hand a variable which shows no such difference by itself may do so in combination with other factors (Morrison, 1967).

\section{Results}

(1) INCIDENCE OF GONORRHOEA

Official statistics for venereal disease are unreliable in Kenya, as in most other countries, and a detailed analysis of hospital returns shows some grotesque discrepancies. Nevertheless it is to be noted that in 1968 over 50,000 cases of gonorrhoea and over 15,000 cases of urethritis were diagnosed in government hospitals in Kenya (population 11 million) and that there has been a steady increase since 1961 when the lowest figure (16,500 gonorrhoea cases) was recorded. This does not include cases treated in city council clinics $(18,400$ cases of both diagnoses together in one V.D. clinic in Nairobi), in mission hospitals, and in all smaller government institutions such as health centres and dispensaries. In this last category alone, as many patients may be treated as in the hospitals. In areas with a high incidence the gonorrhoea-urethritis group may represent up to 10 per cent. of all diagnoses in adult males in hospitals, whereas, in private practice, patients with some form of urethral discharge may constitute up to onequarter of the total (personal communications). These high figures are confirmed in places where the diagnoses were comparatively reliable, such as the special V.D. clinic in Nariobi (Figure). It should be noted that the African population of this town more than doubled during the period concerned and that when treatment became free in 1965 the attendance for all medical services increased rapidly. Nevertheless the data from this clinic confirm the increase in gonorrhoea and NSU, whereas the incidence of

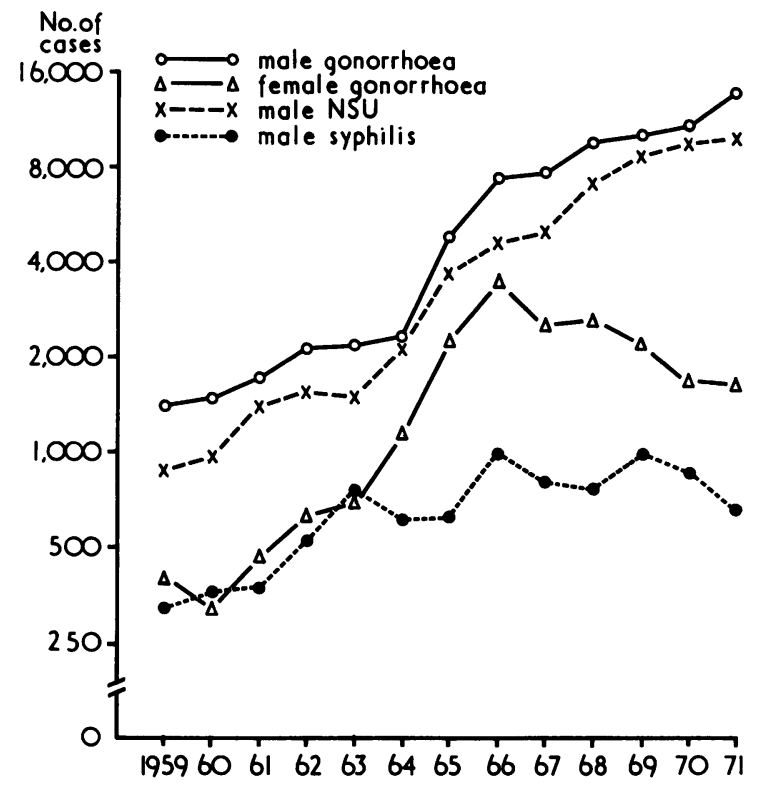

FIGURE Numbers of new cases seen at the V.D. clinic in Nairobi, 1959 to 1971

syphilis remains virtually the same. The male:female ratio among gonorrhoea patients (Figure) increased from its lowest point in $1964(2: 1)$ to $6: 1$ in 1970 and $8: 1$ in the first half year of 1971. As gonorrhoea in the female is often not manifest, this indicates the failure of contact-tracing and is an ominous sign for the control of the disease (Willcox, 1966); especially when it is considered that for syphilis, in which the symptoms are equally obvious in both sexes, the ratio continues to fluctuate around 2:1.

Our own experience, in which the diagnosis of gonorrhoea was confirmed by culture, indicates that between five and ten new cases a day will be found in up-country hospitals and municipal clinics.

In conclusion, not even an approximate figure for the overall incidence of gonorrhoea can be given, but it is certainly a very common disease. Nevertheless, it is our impression that, in sub-Saharan Africa, Kenya has a relatively low incidence and our data do not represent an isolated "problem country"; in many parts of the world gonorrhoea is now the second most common notifiable disease after measles (Lancet, 1970).

(2) AGE

Table I gives the age distribution in the four groups of patients. In a small minority, the age is an estimate. Most patients who could not indicate their 
TABLE I Age and sex of patients

\begin{tabular}{|c|c|c|c|c|c|}
\hline \multirow{2}{*}{\multicolumn{2}{|c|}{$\begin{array}{l}\text { Sex } \\
\text { Gonorrhoea }\end{array}$}} & \multicolumn{2}{|l|}{ Male } & \multicolumn{2}{|l|}{ Female } \\
\hline & & $\frac{\text { Positive }}{11}$ & $\frac{\text { Negative }}{2}$ & $\frac{\text { Positive }}{5}$ & $\frac{\text { Negative }}{18}$ \\
\hline $\begin{array}{l}\text { Age } \\
\text { group } \\
\text { (yrs) }\end{array}$ & $\begin{array}{l}11-15 \\
16-20 \\
21-25 \\
26-30 \\
\text { Over } 35 \\
\text { Unknown }\end{array}$ & $\begin{array}{r}11 \\
224 \\
224 \\
136 \\
62 \\
7\end{array}$ & $\begin{array}{r}2 \\
83 \\
82 \\
50 \\
25 \\
5\end{array}$ & $\begin{array}{r}5 \\
59 \\
37 \\
32 \\
10 \\
5\end{array}$ & $\begin{array}{r}18 \\
131 \\
114 \\
142 \\
45 \\
33\end{array}$ \\
\hline & Total & 736 & 266 & 151 & 523 \\
\hline \multicolumn{2}{|c|}{$\begin{array}{l}\text { Percentage } \\
\text { under } 21 \text { yrs } \\
\text { Percentage } \\
\text { under } 31 \text { yrs }\end{array}$} & $32 \cdot 2$ & $32 \cdot 6$ & 43.8 & $30 \cdot 4$ \\
\hline
\end{tabular}

5-year age group were older women and these were largely found in the F-NEG group.

\section{(3) SOCIAL DATA}

The reasons which led us to study some social parameters may be defined as follows: In many parts of the world the larger proportions of patients with venereal diseases are found among distinct social groups such as the lower social strata, members of migratory or itinerant professions, and other groups characterized by social instability (see Discussion). Virtually all such investigations have been limited to developed western countries, and we wished to discover whether it was possible to localize and describe similar groups in an African country.

We questioned our patients regarding their education (Table II); their occupation and its level (unskilled, skilled or highly skilled) and duration (five categories); the length of time they had lived in their present municipality (six categories); whether they or their family inhabited a house or room to themselves or had to share such accommodation; and finally whether they were married and, if so, shared a regular life with the marital partner. In this last question we originally distinguished four categories, but it appeared from the results that the patients fell into two main groups: those sharing daily life, including a small group who met the partner at least once a week, and those meeting about once a month, irregularly, or never.

Table II serves as an example of a complete frequency distribution on which the statistical analysis was based; namely the variable education in the male patients. This was classified in six categories, coded in values and a mean was determined per clinic group for the gonorrhoea patients, the patients with non-specific urethritis ('non-gonorrhoea'), and the controls.

The other variables were processed in the same way, and are presented here in a simplified form in Tables III and IV*. Table III presents the statistical means for all variables mentioned above. The level and duration of occupation have been disregarded in women as less than 10 per cent. had regular jobs, the overwhelming majority being housewives or schoolgirls. An asterisk in the column of the controls indicates there was a statistically significant difference between the controls and the entire patient group (both GON and Non-GON), whereas an asterisk in the column giving the means for the gonorrhoea patients indicates the same between the patients with and without gonorrhoea.

In regard to the first six variables, apart from marital life, the overall conclusion is that there is a striking similarity between patients and controls. In regard to those variables which might be considered as indicators of socio-economic level and prosperity (education, having a job, status of job, and having a residence of one's own), the groups of patients and controls in the same areas are, remarkably, identical. Regarding those variables which

*A Full protocol of the data for other variables and the code applied can be obtained from the authors.

TABLE II Education of male patients and controls, by residential area

\begin{tabular}{|c|c|c|c|c|c|c|c|c|c|c|}
\hline \multirow{2}{*}{\multicolumn{2}{|c|}{$\begin{array}{l}\text { Variable: } \\
\text { Education of males }\end{array}$}} & \multicolumn{3}{|c|}{ Large towns } & \multicolumn{3}{|c|}{ Small towns } & \multicolumn{3}{|c|}{ Rural } \\
\hline & & \multicolumn{2}{|c|}{$\begin{array}{l}V . D . \\
\text { patients }\end{array}$} & \multirow[t]{2}{*}{ Controls } & \multicolumn{2}{|c|}{$\begin{array}{l}\text { V.D. } \\
\text { patients }\end{array}$} & \multirow[t]{2}{*}{ Controls } & \multicolumn{2}{|c|}{$\begin{array}{l}V . D . \\
\text { patients }\end{array}$} & \multirow[t]{2}{*}{ Controls } \\
\hline Attribute & Value & Gon. & Non-gon. & & Gon. & Non-gon. & & Gon. & Non-gon. & \\
\hline $\begin{array}{l}\text { No schooling } \\
1-3 \text { yrs Primary } \\
\text { 4-6 yrs Primary } \\
\text { Primary certificate } \\
1-6 \text { yrs Secondary } \\
\text { Secondary Cert./Higher } \\
\text { Unknown }\end{array}$ & $\begin{array}{l}0 \\
1 \\
2 \\
3 \\
4 \\
5 \\
-\end{array}$ & $\begin{array}{r}106 \\
33 \\
126 \\
119 \\
38 \\
19 \\
3\end{array}$ & $\begin{array}{r}17 \\
9 \\
25 \\
26 \\
7 \\
7\end{array}$ & $\begin{array}{r}157 \\
26 \\
139 \\
116 \\
73 \\
28\end{array}$ & $\begin{array}{r}24 \\
5 \\
59 \\
25 \\
11 \\
5 \\
1\end{array}$ & $\begin{array}{r}11 \\
2 \\
27 \\
13 \\
15 \\
4\end{array}$ & $\begin{array}{r}67 \\
6 \\
44 \\
41 \\
35 \\
6 \\
5\end{array}$ & $\begin{array}{r}47 \\
17 \\
43 \\
20 \\
15 \\
5\end{array}$ & $\begin{array}{r}19 \\
4 \\
19 \\
14 \\
11 \\
3 \\
1\end{array}$ & $\begin{array}{r}56 \\
15 \\
71 \\
48 \\
22 \\
6\end{array}$ \\
\hline Total & Mean & $\begin{array}{l}444 \\
2 \cdot 0\end{array}$ & $\begin{array}{l}91 \\
2 \cdot 2\end{array}$ & $\begin{array}{l}539 \\
2 \cdot 0\end{array}$ & $\begin{array}{l}130 \\
2 \cdot 1\end{array}$ & $\begin{array}{l}72 \\
2 \cdot 4\end{array}$ & $\begin{array}{l}204 \\
1.9\end{array}$ & $\begin{array}{l}147 \\
1 \cdot 7\end{array}$ & $\begin{array}{l}71 \\
2 \cdot 0\end{array}$ & $\begin{array}{l}218 \\
1.9\end{array}$ \\
\hline
\end{tabular}




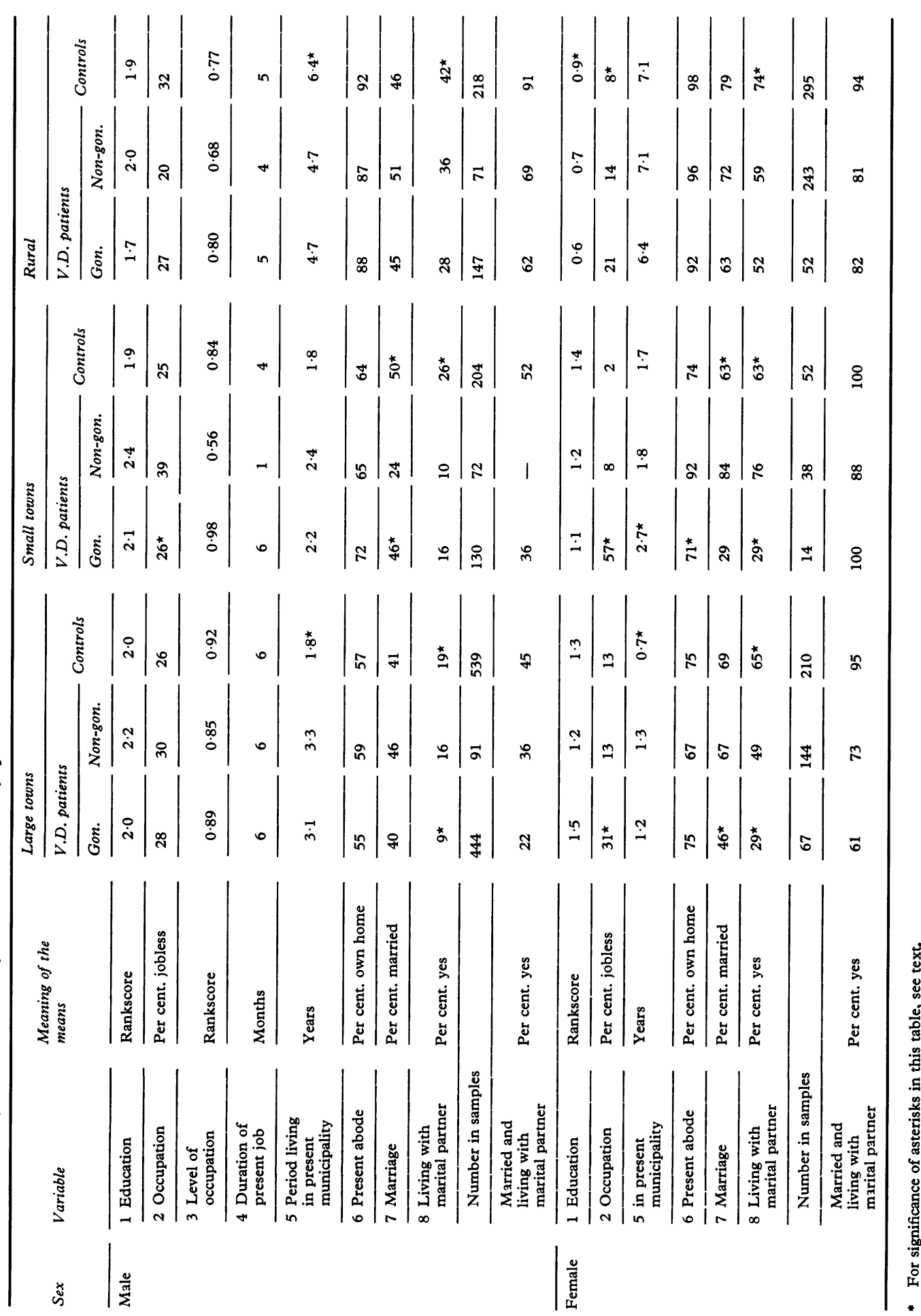


TABLE IV Weights of discriminant function of standardized variables in comparison of patients and controls

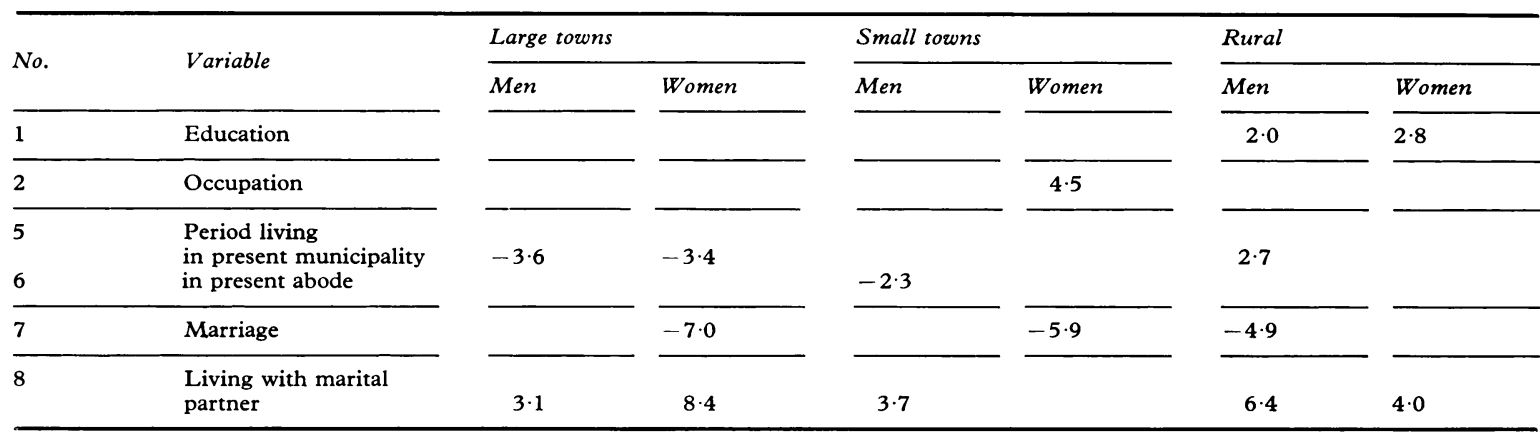

might be indicators of the migratory life and social 'instability' often connected with V.D., the duration of the job also showed no differences, and as to the results of variable 5 , the period that the respondent had lived in his present municipality, the results were contradictory for rural and urban areas. In rural areas, where most of the population still inhabit their native villages, recent immigrants are significantly more frequent among the patients. In the towns, especially the large ones, where the majority of the African population are newcomers, it is remarkable that the patients have been towndwellers for a significantly longer period than the average population as represented by controls.

Of the male patients, only 40 to 45 per cent. were married, but this was not unexpected in this agegroup and the percentage was virtually the same in the controls. Among the women, however, there are many more unmarried and 'jobless' among the patients with gonorrhoea than among the nongonorrhoea group (which in females includes many who had no V.D. at all) or among the controls; we shall see this is explained by the number of prostitutes. It was the last question (variable 8) which proved most helpful in elucidating social determinants influencing the epidemiology of gonorrhoea in an African country. Table III shows, when variables 7 and 8 are compared, that a large proportion of all married respondants met their partner only once a month or, in most cases, even less often, the percentage being invariably higher in towns when compared with rural areas, in men when compared with women, and in gonorrhoea patients when compared with controls, or even-especially in womenwhen compared with non-gonorrhoea patients. The difference with controls was consistent and statistically significant in all geographical areas for both sexes, indicating that this was an important factor in the epidemiology of gonorrhoea and of NSU in men.
The percentages given under variable 8 show how many respondents in the entire group lived with a regular partner; the lowest figure, 9 per cent. among the gonorrhoea patients in the large towns, is impressive. All others were either unmarried or married but living apart. To stress the magnitude of the problem among this last group, we have provided at the bottom of the Table the percentages of those who lived with their marital partner among the married (variable 8 divided by 7); this shows that, in large towns, less than half of all married controls and less than a quarter of the gonorrhoea patients lived with their wives. For the discriminant function (Table IV) all variables were transformed to variance 1 , which facilitates comparison. The size of the weights indicates the 'importance' of the variable. The discriminant function between patients and controls for men in large towns, for instance, reads $y=-3 \cdot 6 x_{5}+3 \cdot 1 x_{8}$. This equation means: the difference between patients and controls in this group can be condensed in the variables $x_{5}$ (period in present municipality) and $x_{8}$, of which $x_{5}$ is slightly more important. Variable 3 and 4 did not appear in any of the functions, and living with the marital partner (8) was the main overall factor. Table V illustrates the extent of the migration of single men to towns and to areas with modern agriculture on large farms (Kericho). In towns the male:female

TABLE V Male:female ratio, 1969 adult population (over 14 years of age)

\begin{tabular}{|c|c|c|c|}
\hline \multicolumn{2}{|l|}{ Towns } & \multicolumn{2}{|l|}{ Districts } \\
\hline Nairobi & $1 \cdot 86$ & C. Nyanza & \\
\hline Nairobi & & (Kisumu) & 0.86 \\
\hline (Africans) & $2 \cdot 20$ & Kericho & $1 \cdot 14$ \\
\hline Mombasa & $1 \cdot 61$ & Machakos & 0.82 \\
\hline Kisumu & $1 \cdot 60$ & Kitui & 0.77 \\
\hline Kericho & $1 \cdot 79$ & Nyeri & 0.80 \\
\hline Machakos & $1 \cdot 69$ & & \\
\hline Kitui & $1 \cdot 84$ & & \\
\hline Nyeri & $1 \cdot 85$ & & \\
\hline
\end{tabular}


ratio for Africans may be even higher (see Nairobi) than these figures, which include the large urban Asian and European minorities. In some rural districts the ratio is $0.5: 1$ in those aged between 25 and 39 years.

\section{(4) PROMISCUITY}

The following data are for patients only, as these potentially embarassing questions were not put to controls.

Table VI gives the percentage of those admitting extramarital intercourse (EMI) during the fortnight before the symptoms started. The percentage between brackets means EMI with more than one partner and in the majority this meant promiscuity with four or more partners.

TABLE VI Admission of extramarital intercourse (between brackets: with more than one partner) (percentages)

\begin{tabular}{|c|c|c|c|c|}
\hline \multirow[b]{2}{*}{ Area } & \multicolumn{2}{|l|}{ Male } & \multicolumn{2}{|l|}{ Female } \\
\hline & Gon. & Neg. & Gon. & Neg. \\
\hline $\begin{array}{l}\text { Large towns } \\
\text { Small towns } \\
\text { Rural }\end{array}$ & $\begin{array}{ll}97(48) \\
96(32) \\
89(56)\end{array}$ & $\begin{array}{ll}87 & (46) \\
96 & (17) \\
82 & (39)\end{array}$ & $\begin{array}{ll}60 & (35) \\
71 & (43) \\
41 & (23)\end{array}$ & $\begin{array}{ll}37 & (20) \\
21 & (5) \\
33 & (17)\end{array}$ \\
\hline Total & $95(47)$ & 88 (35) & $54(31)$ & 34 (17) \\
\hline
\end{tabular}

Very few males attributed the infection to marital contact and even in the small minority who denied EMI, most answers appeared untrustworthy. In the towns, the largest percentage of promiscuous men was found in the 16 to 20 -year age group, up-country it appeared later (21 to 30 years). Most social determinants, such as education, showed no connection at all with the percentage of the promiscuous, except sharing a regular life with one's wife; men of this group usually had had only one extramarital partner and only 19 per cent. were promiscuous.

Female patients often did not know when they had been infected and so could not identify the fortnight preceding the infection; they were also less frank. Nevertheless one-third of the female gonorrhoea patients admitted promiscuity; notably the group with EMI with one partner was smaller than in men, so that the females could be separated more easily into the promiscuous and the faithful. A more detailed analysis confirms this: EMI with one partner was mostly encountered among the unmarried in the 16 to 20-year age group (boy friends), but the women above the age of 20 could be divided in the promiscuous unmarried (usually prostitutes) and the married, of whom only 10 per cent. admitted EMI with a single partner and only 1 per cent. was promiscuous. The promiscuous women were less well educated than the average and very often had no job as well as being unmarried.

\section{(5) PROSTITUTION}

To define a prostitute is difficult and depends on social attitudes in the country concerned. In neighbouring Uganda, Bennett (1964) described a 'spectrum' of sexual unions with variable duration and degree of immediate gain as motivation. The Kiswahili word malaya may have a less factual professional meaning and an aggressive moral condemnation may be implied in answers by males. We stressed in our interviews the definition of a short relationship in exchange for payment in cash or kind. With all these reservations, Table VII demonstrates the importance of prostitution in the epidemiology of gonorrhoea. The figures for men need no comment and even in female gonorrhoea patients one-third admitted being prostitutes, although they were less frank than the men and the real percentage is probably higher. It seems that, in Kenya and many other developing countries, prostitutes constitute the majority of the 'promiscuous women pool'; as this group is so important in epidemiology, prostitutes deserve a closer study. At this point, in addition to the 117 prostitutes met in the general clinics (Table VII), some data from 87 girls in the special clinic in Mombasa-Timboni may be included.

TABLE VII Prostitution (percentages)

\begin{tabular}{|c|c|c|c|c|}
\hline \multirow{2}{*}{ Area } & \multicolumn{2}{|c|}{$\begin{array}{l}\text { Male states } \\
\text { partner prostitute }\end{array}$} & \multicolumn{2}{|c|}{$\begin{array}{l}\text { Female } \\
\text { admits prostitution }\end{array}$} \\
\hline & Gon. & Neg. & Gon. & Neg. \\
\hline $\begin{array}{l}\text { Large towns } \\
\text { Small towns } \\
\text { Rural }\end{array}$ & $\begin{array}{l}81 \\
72 \\
69\end{array}$ & $\begin{array}{l}73 \\
60 \\
61\end{array}$ & $\begin{array}{l}37 \\
43 \\
24\end{array}$ & $\begin{array}{r}19 \\
5 \\
18\end{array}$ \\
\hline Total & 77 & 65 & 32 & 17 \\
\hline
\end{tabular}

This group consisted largely of the smarter and more expensive girls working in the dock area of this town who came for a routine monthly check-up. Virtually none had any symptoms but eighteen (21 per cent.) had gonorrhoea, whereas among prostitutes in the general clinics who had symptoms or were contacts 41 ( 35 per cent.) were infected. In view of the different selection, the difference and, by implication, the value of a monthly check-up is not impressive.

African prostitutes are young: 91 per cent. were between 16 and 30 years old with an almost equal distribution over the 5-year age groups. The 
sophisticated appearance of many of these girls, who speak good English, is deceptive; 55 per cent, had never gone to school and only 8 per cent. had passed the final primary school examination; in Timboni these figures were 50 and 3 per cent. Seven per cent. were married, but they were found almost exclusively up-country and were somewhat older. Full-time prostitutes in urban bars were frequently divorced women (44 per cent.), but it was not clear whether prostitution had followed or preceded the divorce. Three-quarters had had a child, but only one-third more than one, so that 'one-child sterility' due to gonorrhoea could have been common. We traced the racial and tribal origin of 1,322 prostitutes in Mombasa. They represented forty tribes from eight East African countries and only 6 per cent. were working closer than 400 kilometres to their native area. Compared with the general tribal distribution of the town, the tribes were very unevenly represented among prostitutes. Certain linguistic groups seem to specialize in prostitution; some tribes from the west side of Lake Victoria which Bennett (1962) mentioned in Uganda, de Mello (1948) in Kenya, and Laurie (1958) in Tanzania, represented 5 per cent. of the Mombasa girls, although the town is 1,500 kilometres from their home ; Ugandans made up 15 per cent. of the girls, against 1 per cent. in the general population. Among Kenyans, 60 per cent. came from two tribes, both living far from Mombasa.

Prostitutes constitute an important part of the reservoir of undiagnosed gonorrhoeal infections. They are highly mobile (two-fifths had inhabited their present municipality for less than a year) and were not rare in rural areas (Table VII and Bennett, 1964). They appear to contribute considerably to the inter-regional and international spread of gonorrhoea and of partially resistant strains of gonococci.

\section{(6) MEETING PLACE WITH EXTRAMARITAL PARTNER}

We assumed that encounters in bars, brothels, dance-halls, and in the street (termed the BBDS category) were the more casual and usually reflected prostitution and promiscuity; in regard to control of V.D., the first three are the places where girls could be easily traced and regularly investigated, as opposed to encounters in or near the residence of one of the partners, in schools, or at work, a category which might represent more permanent and personal acquaintances.

Table VIII gives the percentages of BBDS encounters among the entire groups and (between brackets) among the respondents who admitted
TABLE VIII Encounters in bar, brothel, dance hall and street (between brackets: of those admitting EMI) (percentages)

\begin{tabular}{|c|c|c|c|c|}
\hline \multirow[b]{2}{*}{ Area } & \multicolumn{2}{|l|}{ Male } & \multicolumn{2}{|l|}{ Female } \\
\hline & Gon. & Neg. & Gon. & Neg. \\
\hline $\begin{array}{l}\text { Large towns } \\
\text { Small towns } \\
\text { Rural }\end{array}$ & $\begin{array}{ll}72 & (74) \\
52 & (54) \\
61 & (68)\end{array}$ & $\begin{array}{ll}59 & (68) \\
33 & (34) \\
53 & (65)\end{array}$ & $\begin{array}{ll}19 & (33) \\
36 & (50) \\
21 & (52)\end{array}$ & $\begin{aligned} 12 & (32) \\
8 & (38) \\
12 & (36)\end{aligned}$ \\
\hline Total & $66(69)$ & 49 (56) & $22(41)$ & 12 (35) \\
\hline
\end{tabular}

EMI. The majority of all encounters of the male patients were in the BBDS category and the men characterized over 90 per cent. of their pick-ups in these places as prostitutes. Our female patients confirmed that soliciting by non-prostitutes in these places is rare, as only 9 per cent. of the non-prostitutes who admitted EMI at all (2 per cent. of the entire group) had met the partner in BBDS. It is then not surprising that both men and women frequenting these places were the most promiscuous (56 and 91 per cent. respectively), against 32 per cent. for both sexes in other meeting-places. The BBDS are almost never visited by married women ( 1 per cent.) and considerably less by males living with their wives ( 38 per cent.) than by the non-married ( 63 per cent.) or the married who are living apart (70 per cent.).

In the BBDS category, by far the most common meeting-place was the typical African bar, an institution in which alcohol consumption and prostitution are usually combined; as Bennett (1964) describes, it is also found in small rural villages and trading centres, where one would hardly expect the existence of such an institution; this is confirmed by figures for our rural patients. The smaller dance-halls closely resemble the bars. Brothels were responsible for only 10 per cent. of male gonococcal infections in towns and were almost never mentioned up-country. However, only half of all male patients had met the partner in the first three places of the BBDS category, where routine medical examination of the girls could be organized. The other half met the partner in the street $(10 \mathrm{per}$ cent.) or in and around the residence of one of the partners ( 35 per cent.), and more than a third of the pick-ups in this category were also prostitutes.

\section{Discussion}

(1) RELIABILITY

Anamnestic data of veneral diseases are notoriously unreliable, but we have no means of obtaining these data other than the admittedly imperfect procedure 
of questioning; we must agree with Brown (1970) that perfectionism in this field leads only to 'give up or stand by'.

On the whole we felt that our patients were unexpectedly frank with one or two exceptions. Women may dodge questions regarding promiscuity and prostitution, whereas men have few inhibitions; a few men feared consequences for their jobs, when this subject was brought up, but other questions did not cause problems.

\section{(2) DISCUSSION OF THE RESULTS}

From this multitude of figures a picture of the epidemiology of gonorrhoea emerges, which may be found in many parts of sub-Saharan Africa. The pattern differs little from that summarized by Willcox (1965a, b; 1966) for a western country. A 'promiscuous female pool' (PFP) with many silent infections infects a larger number of promiscuous males; these men feed back gonorrhoea into the PFP and may also infect a non-promiscuous secondary contact, usually the wife.

Our findings confirm this situation. In Africa, the heart of the problem is that economic changes create a large group of single young men in their sexually most active age. Most are not yet married and may be saving money for the bride price, which later acts as a security for the stability of marriage (Bennett, 1962). In addition, many married men continue to live apart from their wife, especially in the towns, while she looks after the family's land in their rural home area. Again and again, this type of migration has been described as the ecological setting for V.D. in modern East Africa (Paterson, 1925; McElligott, 1951; Wilson Rae, 1951; Bennett, 1962; Kibukamusoke, 1965). In Kenya it has a long history. During the colonial periods western economy was introduced in the towns and the agricultural 'white highlands'; the African tribal areas became labour 'Reserves' and were indeed called so. It was encouraged, if not economically enforced, that men from these 'Reserves', which contained the bulk of the population, should work in the farms of the Europeans leaving their families behind. A comvarison between census figures in 1962 (with even worse male:female ratios than those shown in Table V) and 1969 shows that a permanently settled African urban class of some size is only recently taking shape, but the flow of young men seeking employment is also increasing because of the high birth rate and better education. Paterson (1925), McElligott (1951), Lees (1951), Bennett (1962), and Kibukamusoke (1965) also stressed that migration and urbanization resulted in a breakdown of traditional ethics, which often implied severe sanctions against promiscuity; if this is true, this process now involves most rural areas. However, the evidence regarding the comparative incidence of gonorrhoea in the old times is contradictory; Paterson (1925) stated that 50 years ago it was very rare in rural Kenya, but Kibukamusoke (1965) for Uganda and McKay (1950) and Wilson Rae (1951) for some seminomadic tribes in Kenya, trace it further back.

Wherever there are single men, some women will cater for their sexual needs. Tables VII and VIII suggest that in Kenya the PFP consists largely of prostitutes; this is the case in most developing countries (Tanami and Yamamoto, 1958; Ferreira Marques, 1964; Willcox, 1962; Arya and Bennett, 1967, 1968; Siddhu, Mahajan, and Srivastava, 1969). The good-time girl and promiscuous amateur take over at another stage of development (Härö and Pätiälä, 1957; Rosenthal and Vandow, 1958; Laird, 1961; Willcox, 1962; Beek, 1968; Juhlin, 1968; INSERM, 1969). These Tables also demonstrate that other women, notably those who are married, are not promiscuous but are usually infected as secondary contacts, thus completing Willcox's pattern. The poor education and employment record of the girls, the number of divorcees, and the isolation from their tribal background show that in Africa prostitution may often still be an economic necessity. These factors which promote the spreading of gonorrhoea affect young people especially and our sample of patients appears to be one of the youngest ever described, even in comparison with other studies in Africa (Bennett, 1962; Maffre, Ba, Mattern, Baylet, Gueye, and Wone, 1965; Sieff, 1966). The age pyramid offers some explanation (25 per cent. of Kenyans are aged between 15 and 29 years, 26 per cent. are older, and 49 per cent. are children); with some exceptions (Lomholt and Berg, 1966; Juhlin, 1968; Platts, 1969), and notwithstanding the recent shift towards younger ages, all samples from western countries are still on the average considerably older.

In addition to these social factors, the inadequate routine treatment schemes, the high proportion of strains of gonococci with diminished sensitivity (Verhagen and others, 1971), and the omission of contact-tracing by overburdened health services result in a high incidence of infection. Moreover, such social factors as irregular married life occur with some variation in almost all classes and areas; this may explain wby Table III shows that gonorrhoea at least in men, is becoming what we would like to call 'socially holoendemic'. Further data not given in Table III regarding profession, tribe, and habitat were studied, but a regular married life remained the only parameter clearly influencing the incidence of gonorrhoea. Other authors have pointed to low 
grade education (Willcox, 1962; Fiumara, Appel, Hill, and Mescon, 1959; Ekström, 1970), itinerant occupations (Lees, 1951; Wilson Rae, 1951; Shepard and Page, 1955; British Cooperative Clinical Group, 1956; Härö and Pätiälä, 1957; Ekström, 1970), low income, unemployment, and slum housing (Siddhu and others, 1969; Platts, 1969; Brown, 1970; Ekström, 1970). Gonorrhoea has also been found to be common among university students (Arya and Bennett, 1967; Juhlin, 1968) and especially among immigrants (Laird, 1963; Willcox, 1963c). None of these groups could be singled out in Kenya.

In this connection, a comparison with controls, which has rarely been made, appears to be important. Our findings seem, for instance, to confirm our concept of the urban male patient, whom we visualized as a poorly educated, unemployed, young, recent arrival, living in overcrowded conditions. Yet the same circumstances were found proportionally in the controls who represent the general public in clinics visited by over 90 per cent. of the population. Too many general statements regarding the background of V.D. have been made on the basis of observations in special clinics catering for exposed groups, which show only 'the tip of the iceberg' (Brown, 1970).

It is the promiscuous female patient who can be identified socially, in regard to poor education, unemployment, migratory habits, marital breakdown, and tribal origin.

\section{(3) NON-SPECIFIC URETHRITIS}

As mentioned above the male gonorrhoea-negative group was made up almost exclusively of cases of NSU. The Figure and our findings show that this condition may be as common in developing countries as in the west; moreover, in health services with inadequate diagnostic facilities, it is often not distinguished from gonorrhoea and therapeutic failures in NSU undermine confidence in any treatment scheme for gonorrhoea. Patients with chronic NSU burden the health services.

Although their general social background is the same as that of gonorrhoea patients, they appear to form a less active group in regard to promiscuity, prostitution, and BBDS encounters.

Interestingly, the same finding was well documented by Laird (1958) and Oller and Wood (1970) in Great Britain. The female gonorrhoea-negative group was heterogenous and consisted largely of women with gynaecological complaints, but it offers an interesting contrast with the group of women with gonorrhoea, especially in regard to questions for which there were no controls.

\section{(4) CONCLUSIONS}

It is easier to indicate the wrong approach to the problem of gonorrhoea, which is very common all over tropical Africa, than to propose effective measures. In many places the prevalence of the disease is considered to be an indictment of the community, but candour regarding the extent of the problem is a prerequisite for a realistic approach. The self-image of an indiscriminately promiscuous community (which in view of our findings in regard to the regularly married is wrong), ostracism against prostitutes and emotional outbursts blaming a particular sex or group of persons are of no help.

In view of the widespread migration, any V.D. campaign should be nationwide in Africa; areas isolated from the spread of gonorrhoea no longer exist and this may explain why a high proportion of gonococcal strains with diminished sensitivity is so widespread (Verhagen and others, 1971). The effect of the regular investigation of prostitutes must not be overestimated (Willcox 1963a, b), as it has been shown that even when this is done (as at Timboni) the rate of infection remains high and that many encounters with promiscuous women take place in residential areas and in the street.

Apart from an adequate dosage scheme (Verhagen and others, 1971) which will cure the male patient and decrease the feed-back of infections into the PFP, a more lasting effect may only be expected from the social changes at present being promoted in Kenya: large housing schemes should encourage the development of a stable urban class and the development of infrastructure in rural areas should diminish migration into the towns for which there is no economic outlet.

\section{Summary}

In seven urban and rural areas in Kenya, 1,533 patients were investigated for gonorrhoea and the social background of positive and negative cases was compared with that of controls. Statistical analysis showed that the migration of single men, caused by economic change in modern Africa, was the main social phenomenon connected with the high incidence of gonorrhoea. Patients and controls were remarkably similar otherwise and, contrary to other societies, no distinct high-risk groups were found. The epidemiological picture was completed by a high level of sexual promiscuity between single men and prostitutes mainly centered on bars.

We wish to thank our interviewers, Miss Florence Hongo and J. Owino; Mrs. W. Nicholls and Dr. C. Verhagen for revising the coding; and also all co-authors and 
acknowledged collaborators in the first paper by our group (Verhagen and others, 1971), who besides taking part in the bacteriological studies also contributed directly to the present study.

\section{References}

ARYa, O. P., and Bennett, F. J. (1967) Brit. F. vener. Dis., 43, 275

- (1968) Ibid., 44, 160

BEEK, C. H. (1968) Ned. T. Geneesk., 112, 989

BenNETt, F. J. (1962) E. Afr. med. F., 39, 332 (1964) Ibid., 41, 163

British CoOperative Clinical Group (1956) Brit. $\mathcal{F}$. vener. Dis., 32, 21

BRown, W. J. (1970) Ibid., 46, 118

EKSTRÖM, K. (1970) Ibid., 46, 93

FERREIRA MARQues, J. (1964) Derm. trop., 3, 139

Fiumara, N. J., Appel, B., Hill, W., and Mescon, H. (1959) New Engl. f. Med., 260, 863

Härö, A. S., and Pätiälä, R. (1957) Brit. F. vener. Dis., 33, 70

INSERM, Report (1969) Con. méd., 91, 2656

JuHLIN, L. (1968) Acta derm.-venereol. (Stockh.), 48, 75

KibukAmusoke, J. W. (1965) Trans. roy. Soc. trop. Med. Hyg., 59, 642

LAIRD, S. M. (1958) Brit. F. vener. Dis., 34, 137

- (1961) Ibid., 37, 70

- (1963) Ibid., 39, 101

Lancet (1970) Editorial, 2, 250

LAURIE, W. (1958) Brit. F. vener. Dis., 34, 16

LEES, R. (1951) Ibid., 27, 127

LOMHOLT, G., and BERG, O. (1966) Ibid., 42, 1

Maffre, E., Ba, H., Mattern, P., Baylet, R., Gueye, C. and Wone, I. (1965) Bull. Soc. méd. Afr. noire Langue franç., 10, 603

McElligotT, G. L. M. (1951) Brit. F. vener. Dis., 27, 122

MCKaY, D. H. (1950) E. Afr. med. F., 27, 451

Mello, J. DE (1948) Ibid., 25, 14

MoRRIsoN, D. F. (1967) 'Multivariate Statistical Methods', pp. 130-133. McGraw-Hill, New York
OlleR, L. Z., and Wood, T. (1970) Brit. f. vener. Dis., 46, 96

Paterson, A. L. (1925) Kenya med. F., 1, 366

Platts, W. M. (1969) Brit. F. vener. Dis., 45, 61

RAE, A. M. WILSON (1951) Ibid., 27, 118

Rosenthal, T., and Vandow, J. (1958) Ibid., 34, 94

Shepard, A. C., and Page, W. J. (1955) Publ. Hith Rep. (Wash.), 70, 986

Siddhu, C. M. S., Mahajan, R. C., and Srivastava, B. C. (1969) Antiseptic, 66, 843

Siefr, B. (1966) Med. Proc., 12, 224

Tanami, Y., and Yamamoto, J. (1958) Bull. Wld Hlth Org., 19, 519

Verhagen, A. R., van der Ham, M., Heimans, A. L., KRANENDONK, O., and MAINA, A. N. (1971) Ibid., 45, 707

Willcox, R. R. (1962) Brit. f. vener. Dis., 38, 37

- (1963a) Antiseptic, 60, 6

- (1963b) Ibid., 60, 171

- (1963c) Brit. F. vener. Dis., 39, 214

- (1965a) Ibid., 41, 287

- (1965b) Acta derm.-venereol. (Stockh.), 45, 302

- (1966) Ibid., 46, 460

Déterminants sociaux et épidémiologiques pour la gonococcie dans un pays de l'Afrique de l'Est

\section{SOMMAIRE}

Dans sept zones urbaines et rurales du Kenia, on entreprit des recherches sur la gonococcie chez 1553 malades; la situation sociale des cas positifs ou négatifs fut comparée à celle des témoins. L'analyse statistique montra que le phénomène social le plus important quant à la haute incidence de la gonococcie était la migration des célibataires, due au changement économique dans l'Afrique moderne. Pour le reste, les malades et les témoins étaient remarquablement identiques et, contrairement à ce que l'on voit ailleurs, on ne trouva pas de groupes à haut risque distincts. Le tableau épidémiologique se caractérisa par la promiscuité entre les célibataires et les prostituées, concentrées principalement dans les bars. 